\title{
p4c after auschwitz: on immanence and transcendence in education
}

\author{
gert biesta ${ }^{1}$ \\ brunel university, london, united kingdom
}

\begin{abstract}
In this paper, I provide a response to papers that were written in response to the keynote I presented at the 2017 ICPIC conference in Madrid and to the written version of this keynote, published in this journal. I try to clarify what was 'at stake' in the paper, namely an attempt to respond to Adorno's question about the (im)possibility of education 'after Auschwitz,' and highlight that the main theme underlying my arguments concerns the difference between immanence and transcendence and how this 'reflects' upon education. I try to show why (the possibility of) transcendence matters, educationally and for our existence as subject. I try to clarify that the interest in what it means to exist as subject and what education may have to do in relation to this is not meant as another normative blueprint for education but rather tries to engage with the 'experience of freedom,' the experience that we can act and can act differently. And I try to clarify that all this is not an attempt to determine what the subject is, but an attempt to come to terms with the question -- which is there for each of us - as to what it might mean to exist as subject.
\end{abstract}

keywords: exist as subject; transcendence; education after auschwitz.

\section{fpc após auschwitz: sobre imanência e transcendência na educação}

resumo

Neste artigo, forneço uma resposta aos trabalhos que foram redigidos em resposta à minha palestra no último congresso ICPIC de 2017 em Madri, publicada neste mesmo volume e periódico. Tento esclarecer o que estava "em jogo" no artigo, ou seja, uma tentativa de responder à pergunta de Adorno sobre a (im) possibilidade de educação "após Auschwitz" e destacar que o tema principal subjacente aos meus argumentos diz respeito à diferença entre imanência e transcendência e como isso "reflete" sobre a educação. Tento mostrar por que (a possibilidade de) a transcendência é importante, educacionalmente e para a nossa existência como sujeitos. Procuro esclarecer que o interesse no que significa existir como sujeito e o que a educação pode ter a fazer em relação a isso não pretende ser outro modelo normativo para a educação, mas sim tenta envolver-se com a "experiência da liberdade", a experiência de podermos agir e agir de forma diferente. E tento esclarecer que tudo isso não é uma tentativa de determinar o que é o sujeito, mas uma tentativa de chegar a um acordo sobre a questão - que existe para cada um de nós - sobre o que pode significar existir como sujeito.

palavras-chave: existir como sujeito; transcendência; educação após auschwitz.

\footnotetext{
${ }^{1}$ E-mail: gert.biesta@brunel.ac.uk
} 
p4c after auschwitz: on immanence and transcendence in education

\section{fpn después de auschwitz: sobre la inmanencia y la transcendencia en educación}

resumen

En este artículo, doy una respuesta a los artículos que se escribieron en respuesta a la conferencia que presenté en el congreso del ICPIC de 2017 en Madrid y a la versión escrita de esta conferencia, publicada en este mismo número y revista. Trato de aclarar lo que estaba en juego en ese texto, es decir, un intento de responder a la pregunta de Adorno sobre la (im) posibilidad de la educación "después de Auschwitz", y resaltar que el tema principal de mis argumentos se refiere a la diferencia entre inmanencia y trascendencia y cómo esto se "refleja" sobre la educación. Trato de mostrar por qué (la posibilidad de) la trascendencia importa, educativamente y para nuestra existencia como sujetos. Trato de aclarar que el interés en lo que significa existir como sujeto y lo que la educación puede tener que hacer en relación con esto no se entiende como otro plan normativo para la educación, sino que trata de comprometerse con la "experiencia de la libertad", la experiencia de poder actuar y actuar de manera diferente. $Y$ trato de aclarar que todo esto no es un intento de determinar lo que es el sujeto, sino un intento de llegar a un acuerdo sobre la pregunta - que está allí para cada uno de nosotros - en cuanto a lo que podría significar existir como sujeto.

palabras clave: existir como sujeto; transcendencia; educación después de auschwitz 
p4c after auschwitz: on immanence and transcendence in education

I am grateful to Walter Kohan and David Kennedy for the opportunity to publish a version of the keynote I presented at the 2017 ICPIC conference in Madrid in Childhood \& Philosophy, together - which is quite unique - with the power point presentation I used at the conference. I am also grateful for the time, energy and attention of the 15 authors of the papers that respond to my presentation (either to the oral or the written version, or to both), and to Marina Santi, one of the other keynote speakers, who, in the written version of her presentation, also makes extensive and generous reference to my presentation. In addition to all this, I have been given the opportunity to write a brief response to the responses. This is almost too much, but I will nonetheless to say something about some of the main themes and issues I see emerging from the discussion. ${ }^{2}$

When accepting the invitation to present at the conference, I was well aware of one particular risk, namely that the people I would be addressing would simply conclude that my understanding of what goes on in philosophical work with children and young people ${ }^{3}$ was lacking or even just wrong. This is why I have emphasised that I am speaking about this work as an outsider, and why I have tried to be as precise as possible in describing my particular encounters with philosophical work with children and young people. It is also the reason why I have presented my contribution as a question for those doing philosophical work with children and young people, and not as a judgement about that work or a critique of it. I was pleased to see that several of the authors of the response papers recognise my question - the question about the 'I' in philosophical work with children and young people - and were able to point to scholarship within the field, particularly the work of Ann Sharp, that resonates with this question (see particularly the papers by Patricia Hannam and Riku Välitalo).

\footnotetext{
2 I apologise that I will not be able to engage in detail with all the papers. Perhaps there will be opportunities for this in the future.

${ }^{3}$ I use this longer descriptive phrase because to me P4C still sounds more like a brand of toothpaste.
} 
p4c after auschwitz: on immanence and transcendence in education

From my perspective the question of the 'I,' and the particular way in which I am trying to approach it, namely as an existential question, a question of what it might mean to exist as (an) ' $\mathrm{I}$ ', is receiving insufficient attention in contemporary educational discourse and practice, where it has been replaced by a wide range of explanatory discourses mostly stemming from psychology, sociology or a combination of the two. Part of the ambition of my keynote, in as far as I wanted to have ambitions, was to ask whether this particular question had perhaps also moved to the margins of philosophical work with children and young people. Stefano Oliverio did a helpful job in rephrasing my question by asking, using ideas from Alfonso Lingis, whether philosophical work with children and young people is perhaps too strongly located in and orientated towards the building of rational communities, thereby forgetting the important work with reference to the 'other' community, the community of those who have nothing in common, as Lingis calls it - the community of subject-ness, not of identity, to put it in my own terms. I found this rephrasing very helpful, and was also encouraged to read that those who know the field of philosophical work with children and young people much better than I do highlighted the existence of approaches that appear to take some of my concerns 'on board.'

Just as there was a risk that responses to my keynote would end up in a discussion about correct and incorrect understandings of philosophical work with children and young people - which luckily did not really happen - there is a similar risk in writing this response, as it is tempting to go through the papers, point at misunderstandings and misinterpretations of my arguments, and leave it at that. This is not the kind of discussion I am keen to get into, not just because I believe that such discussions are much better conducted at the kitchen table than in paper-response-and-response-to-response-cycles, but also because questions of (mis)understandings and (mis)interpretations point back at the effectiveness of the original communication. There is, in other words, also a job for me to do in further refining the expression of my thoughts, ideas and observations. 
I am beginning to see, therefore, why Arie Kizel might think that my ponderings amount to an endorsement of the acceptance of the status quo. This is not what I intended - the opposite is actually the case - but I can see that my focus on the question how we gain a perspective on and 'work through' our desires, may seem to suggest that all the work that needs to be done is on 'our' side, rather than that it would require that we turn towards the world. What I was trying to highlight, particularly in a world that seems to be driven by desires - an 'impulse society,' as I called it - is the need not to simply accept desires as they manifest themselves, but always to ask whether the desires we encounter in ourselves are desires worth having and worth pursuing. Sometimes the answer will have to be 'no' - for example when we encounter in ourselves a desire for pure identity in which there is no place for any other identity - but sometimes our answer will be 'yes,' in which case it is the world that needs repairing rather than that our desires need to be transformed.

For me the question of our orientation towards the world in relation to which our desires exist, is a main theme in my discussion about intelligent adaptive systems, where I asked whether such systems are able to generate the question whether the environment they are adapting to - or, in Deweyan terms, the environments with which they seek to established co-ordinated transaction - is an environment they should be adapting to, an environment worth adapting to. Precisely in this question I am therefore highlighting the need to raise critical questions about (our relationship with) the world, rather than just accept it and adjust to it. For me this is a key political question and I was pleased to see how Darren Chatty recognised the centrality of this question, and took it up in relation to the community of philosophical inquiry itself, thus bringing questions about the politics of philosophical work with children and young people sharply into view. With regard to his question whether the idea of 'grown-up-ness' is commensurate with Lipman's notion of 'reasonableness,' my answer is no, mainly because in my view what ends up as being seen as reasonable is always the outcome of our answer to the question what is desirable, not something that comes before it and 
p4c after auschwitz: on immanence and transcendence in education

can settle it. I am, in other words, not advocating the 'taming' of our desires by reason, but the selection and transformation of our desires so that they can support ways of living well, democratically and sustainably. This is why I find Spivak's idea of education as the rearrangement of desires attractive.

The question what intelligent adaptive systems are able to do and are not able to do, brings me to concerns raised by Megan Laverty and Maughn Gregory about my references to and interpretation of Dewey and fellow pragmatists. I agree with Megan and Maughn that Dewey has important things to say about education, inquiry, critique, community, communication, thinking and democracy. The problem I tried to indicate, however, or the concern I tried to raise, is that there is something lacking in the underlying 'paradigm' of Dewey's thought, which I do want to characterise as a paradigm of intelligent adaptation. Dewey presented this paradigm first in his 1896 paper The Reflex-Arc Concept in Psychology, and throughout his long and fruitful career this, in my view, has remained the theoretical - and perhaps some might say: ontological - 'template' for his work. We can find it in books such as How We Think (1910; 1933), although I am inclined to say that it receives its most elaborate treatment in Human Nature and Conduct (1922), and is also central to Logic: The Theory of Inquiry (1938) and the lesser-known book, co-authored with Arthur F. Bentley, Knowing and the Known (1949).

While there are many aspects of this discussion that are better suited for the kitchen table - such as the 'technical' but nonetheless crucial point that what sets off the process of inquiry for Dewey is not an interruption from the outside but a conflict between different habits on the side of the organism - my main concern about Dewey's paradigm is that it is a paradigm of immanence. And whereas learning 'belongs' to this paradigm - and one could argue, as I have done (see, for example, BIESTA \& BURBULES, 2003), that Dewey's theory of learning remains innovative, sophisticated and powerful, as does his theory of communication - the theme of my presentation and paper is actually the question of (the possibility of) transcendence, which is where I locate teaching and the experience of being taught, 
and where I think that the work of education (conceived as Erziehung, not as Bildung; see BIESTA, 2016a) has its place. ${ }^{4}$

One could of course argue that this is a minor theoretical difference, and one could also argue that Dewey's great step forward was to highlight all the creative possibilities of the paradigm of immanence against the very scientism he has sometimes been accused of. ${ }^{5}$ But the possibility I sought to explore in my presentation and paper was whether there might be limits to immanence educational limits, political limits, humane limits, if that expression makes sense and whether therefore there might be a need to re(dis)cover and come to terms with the phenomenon and the experience of transcendence, not seen as some kind of complicated (let alone: religious) metaphysical event, but first and foremost as a very everyday experience: you speaking to me and I speaking to you. While I do explore this experience along philosophical and educational lines - where, with regard to the first field I consider myself an amateur and with regard to the second a specialist ${ }^{6}-\mathrm{I}$ also made an attempt to invoke this experience at the very start of my presentation and my paper. ${ }^{7}$ It is perhaps remarkable, if I have read all the responses with sufficient care, that this 'opening' has not really been taken up by those responding (though it may have done some work 'outside' of the realms of discourse and argumentation, of course).

This brings me to the other issue I raised in relation to the paradigm of intelligent adaptive systems, namely that such systems are unable to receive, as I put it, or, more specifically, that they are unable to be spoken to, to be addressed, to be taught or, to say it in a very precise way: to receive (a) teaching. This is another way of saying that such systems are immanent - that transcendence, the

\footnotetext{
4 See particularly my most recent book, The Rediscovery of Teaching (BIESTA, 2017).

${ }^{5}$ This is the reading of Dewey I still find of crucial importance, also against contemporary forms of scientism in science, education and society more widely - see, for example, BIESTA, 2016b.

${ }^{6}$ My insistence on separating philosophy and education and identifying with the latter and not with the former is perhaps best understood by way of an analogy: while I did learn to play the oboe, just as I did learn how to 'do' philosophy, I did not become a professional oboe-player and in that sense, it would be presumptuous to locate myself inside the rational community of oboists. Or with another analogy: despite all the possible connections and interconnections between education and philosophy - happy and troubled ones (see BIESTA 2014) - philosophy is not my 'sport.'.

${ }^{7}$ By the way, I think that Marina Santi did exactly the same when, at the start of her presentation, she spoke in Italian, a language obviously not 'mastered' by the majority of the audience.
} 
p4c after auschwitz: on immanence and transcendence in education

experience of being spoken to, of being addressed, by someone else, radically from the outside, is not a possibility. Does this matter? My paper may perhaps give the impression that this is mainly a theoretical and philosophical issue and, when viewed in that way, perhaps not more than a preference one might have. But what is at stake her, at least for me (and perhaps I should have been more explicit about this), is the fact that in Nazi Germany many had learned a lot, were very cultivated and 'gebildet,' but, maybe because of this and definitely despite of this, appeared to have been lacking the 'capacity's to be addressed, the 'capacity' to let themselves be addressed. This is what is at stake in my critique of immanence and in my 'case' for transcendence. It is why I am worried about education systems that, geared as they are towards learning, may have forgotten to pay attention to what may break through all the learning, and what needs to break through, in order to try to keep children and young people 'open' towards the world. It is also somewhere here - or perhaps: exactly here - that Adorno's call for the possibility of education after Auschwitz (ADORNO, 1971, pp. 88-104) has its place, and my concern for (the possibility of) transcendence in education is, in a sense, my response to this call.

One could read my response to this call - and the position I try to outline in my presentation and paper - as the expression of just another moral or educational preference, so that the case for grown-up-ness, for living with the question whether 'our' desires are the ones we should be desiring, becomes a socialising and normalising educational 'project.' Several authors, I think, hint at this way of reading my contribution - see, for example, Magda Costa-Carvalho's contribution - and some authors even see my paper as an argument against children and their perspectives (which is a point I read, for example, in Claire

\footnotetext{
8 I put 'capacity' in quotation marks to indicate that this is not simply some kind of ability we can acquire. Perhaps it is the opposite. Perhaps the fundamental 'structure' of the soul is to be found in its openness, its addressability or, with a word coined by ROTH (2011), its 'passability,' and it is the construction of the ego that begins to close down the soul, begins to put borders and barriers around it. These thoughts are speculative, and I am aware that not everyone will appreciate the language, but they are nonetheless meant seriously.
} 
Cassidy's paper $\left.^{9}\right)$. This, as one may appreciate, is not what I intended. I am not suggesting a new or different aim for education more generally and for philosophical work with children and young people more specifically. I am, in other words, not proposing another rational community into which children and young people ought to be socialised. Rather, I am interested in the question what it means to exist as subject and what education may have to do with this. And my concern is that in contemporary education this question has been marginalised and in some cases, has even disappeared, and has been replaced by questions of learning, of meaning making, of comprehension and signification, as I discuss in the paper.

The following lines from my paper bring the two issues - of existing-assubject and of the importance of transcendence - together.

(O)ur subject-ness is being put 'at stake' in situations where we encounter a responsibility or, to be more precise, where I encounter a responsibility, and where it is up to me - and no one else can do that for me - to take responsibility for this responsibility or to walk away from it. And in both 'options' our freedom, our possibility to say yes or no, to stay or walk away, to go with the flow or offer resistance, comes into play. The call to subject-ness is therefore not an act of suppression - it is not a call to give up our freedom - but is a kind of 'double move' where, by being called into the world we are also called to come into a relationship with our freedom. It is less the case that in this double move our subject-ness emerges, as such a description would run the risk of turning subject-ness into a thing, and more accurate to say that in this double move our existing as subject is 'at stake,' matters, becomes relevant and hence becomes real.

At stake in my presentation and paper, in other words, is the question whether education can (still) make it possible for us to exist as subject, that is, to come into a relationship with our freedom, with our possibility to say yes or no, stay or walk away, go with the flow or offer resistance. Marjan Simenc, who, by the way, takes the metaphor of the robot vacuum cleaner into exciting new

\footnotetext{
${ }^{9}$ Claire raises the question whether grown-up-ness is ultimately an 'adult' criterion applied to children and therefore something that prevents children from appearing as children (my phrase) rather than as deficient adults (my phrase as well). While I agree that the phrase is not 'baby talk,' the point I am trying to make is that the question of grown-up (or with the term I actually prefer: non-ego-logical) existence is an empirical question and not an ontological question, so to speak. I am not suggesting that children are by definition unable to exist in non-ego-logical ways and adults are - this, for me, is entirely open, and I would actually contend that I see many young people who are much better at existing in non-ego-logical ways than older people.
} 
p4c after auschwitz: on immanence and transcendence in education

directions, quotes Gunter Gorhan and to me what is contained in this quote comes very close to what I am 'after' in my paper; it comes very close to the concern I am concerned about, so to speak. I quote:

\begin{abstract}
Man, this 'unfixed animal' (Nietzsche) open to its own transcendence insofar as he has not resigned and become reduced to mere mechanics, albeit extremely sophisticated, but still 'final,' stabilised - will always have to revisit the question of meaning. To put it differently: man, insofar as he is not 'fixed' but remains human, must ensure that the meaning of his being and his existence remain an outstanding issue. (GORHAN, 2006, p.5 quoted in SIMENC)
\end{abstract}

This is indeed key to what I am trying to suggest - not as a theoretical possibility but as an existential and hence political issue - namely that human beings, if they seek to remain human, must ensure that the meaning of their being and their existence remains an outstanding issue. And it is precisely in relation to this that I see a task for education, that is, to keep this question of the meaning of our being and our existence remains an outstanding issue, that is, a question we always have to encounter anew, a question that is always ahead of us and before us, and therefore always troubles us, always interrupts us. In precisely this sense, grown-up-ness is not a state or outcome of a trajectory, not something that can ever be achieved, but rather something that remains an ongoing challenge, an issue that is always outstanding. ${ }^{10}$

For me, this hints at a conception of the person which, to a large a degree is articulated very well by Laurance Splitter's discussion of the work of Davidson. While I am slightly more reluctant to speak of this in terms of awareness perhaps, with Levinas, I would say that this awareness is precisely generated by the experience of being addressed, of being spoken to - the underlying view about the existence of the human being as person, a being 'open to its own transcendence' (Gorhan), as necessarily seeing itself 'as one among others' (Splitter), comes, in my view, close to what I have been trying to articulate. Laurance thus shows, and I am grateful for this, that analytic philosophy may have more to offer in support of the 'case' I am trying to make than my remarks in the beginning of my paper suggested.

\footnotetext{
${ }^{10}$ I am intrigued by Marjan's idea of the third subject position and would like to understand this better - something that needs some serious kitchen table time.
} 
This brings me to my final observation, which is in response to the paper by Karin Murris. As with all papers, there is much more in this paper than I can do justice to, but I would like to highlight one issue, which has to do with 'existential thrust' (a phrase used by Stefano Oliverio) of my argument, namely the fact that I am interested in the question as to what it means to exist as subject. This existential question is, therefore, not a question about what the subject is. It is, in other words, not an attempt to theorise or categorise the subject. In the first chapter of my book The Rediscovery of Teaching I refer to the existential question of existing as subject as a first person question - one could also say: a first person perspective question and I distinguish this explicitly from what I characterise as third person perspectives on the subject that seek to theorise the subject 'from the outside,' so to speak, as a 'thing,' to put it a bit crudely. My sense is that what Karin is offering is a third person perspective on the subject - for example when she writes that "(f)or posthumanists, the subject is not an individual with distinct boundaries, but is 'spread out'..." - and it is here that there is a remarkable and potentially important 'gap' between what Karin seeks to do and what I am after. Of course, the detail of this discussion is for alter, but my main concern with third person perspectives on the subject is that, in a sense, they do not 'touch' the existential, first person question 'burden' of existing-as-subject. A slightly different way of putting it, is to say that many of the claims Karin makes are undecidable - there are, after all, arguments for and against the idea that the subject is an individual with distinct boundaries and I don't think that references to quantum theory are going to solve this problem for $\mathrm{us}^{11}$-- and therefore it is entirely open whether such claims may help or hinder in our attempts at existing as subject, and may also be entirely irrelevant when push comes to shove.

To conclude: I am extremely grateful for the wide range of carefully crafted responses to my presentation and paper. I am aware that I have only been able to touch upon a few bigger themes and have not been able to engage with the detail

\footnotetext{
${ }^{11}$ If I see it correctly, Barad's reading of quantum theory seems to miss the point that the claims made by quantum theory apply to the sub-atomic level and therefore cannot that easily be transposed to the atomic level.
} 
p4c after auschwitz: on immanence and transcendence in education

of the response. Nonetheless I hope to have added some further ideas for the important conversation about the educational potential of philosophical work with children and young people.

\section{references}

ADORNO, TH.W. Erziehung zur Mündigkeit. Vorträge und Gespräche mit Hellmut Becker 1959-1969. Frankfurt am Main: Suhrkamp Verlag, 1971.

BIESTA, G.J.J. \& BURBULES, N. Pragmatism and educational research. Lanham, MD: Rowman and Littlefield, 2003.

BIESTA, G.J.J. Is philosophy of education a historical mistake? Connecting philosophy and education differently. Theory and Research in Education 12(1), 65-76, 2014,

BIESTA, G.J.J. Who's afraid of teaching? Heidegger and the question of education (Bildung/Erziehung). Educational Philosophy and Theory 48(8), 832-845, 2016 a.

BIESTA, G.J.J. Democracy and education revisited: Dewey's democratic deficit. In S. Higgins \& F. Coffield (Eds), John Dewey's education and democracy: A British tribute (pp. 149169). London: IoE Press, 2016b.

BIESTA, G.J.J. The rediscovery of teaching. London/New York: Routledge, 2017.

ROTH, W.-M. Passability. At the limits of the constructivist metaphor. Dordrecht/Boston: Springer Science \& Business Media, 2011.

received in: 20.9.2017

accepted in: 22.9.2017 